\title{
Structure of a solitary and a colonial species of Stephanoscyphus (Scyphozoa, Coronatae) with observations on periderm repair
}

\author{
D. M. Chapman \& B. Werner \\ Anatomy Department, Dalhousie University; Halifax, Canada, \\ and \\ Biologische Anstalt Helgoland (Zentrale); \\ Hamburg 50, Federal Republic of Germany
}

\begin{abstract}
KURZFASSUNG: Struktur einer solitären und einer koloniebildenden Art von Stephanoscypbus (Scyphozoa, Coronatae) mit Beobachtungen über den Peridermersatz. Dieser Beitrag stellt die erste eingehende Studie über die Mikroanatomie je einer typischen solitären und koloniebildenden Art des Genus Stepbanoscyphus dar, das der Scyphozoenordnung Coronatae angehört. (Die atypische Form ist die in Japan endemische Species S. racemosus.) Die morphologische Gliederung des Körpers in Kopfteil (Capitulum), Calix und Stielabschnitt wird beschrieben. Die Coronatenpolypen zeichnen sich durch den Besitz eines Ringkanals im Kopfabschnitt aus, der mit dem Coelenteron durch 4 perradiale Offnungen in Verbindung steht. Ein Teil der Wandung des Ringkanals besitzt bemerkenswerte intercelluläre, intraepitheliale und unverzweigte elastische Fibern, die senkrecht zur Oberfläche des Epithels orientiert sind. Die komplexe Natur des Muskelsystems steht in Zusammenhang mit dem Besitz des Ringkanals. Das Ektoderm über seiner medianen Wand hat Längsmuskeln, die sich mit den Radialmuskeln der Mundscheibe vereinigen. Beide Muskelkomplexe bilden zusammen die 4 interradialen, abgeflachten, röhrenförmigen Muskelstränge, die in aboraler Richtung verlaufen und als Retraktoren dienen; sie enthalten im Inneren Cnidoblasten. Die proximale Tentakelmuskulatur geht von der medianen Wand des Ringkanals aus, während für das distale Ende des Tentakels eine feine Längsmuskulatur charakteristisch ist. Das solide Innere der Tentakel besteht aus einer Reihe von großvakuoligen Entodermzellen, die periphere Fibrillenringe unbekannter Funktion tragen. Die Schicht zwischen Ekto- und Entoderm besteht aus einer dünnen, zellfreien Mesolamella (Basalmembran). Die Epithelien des Calix und einiger anderer Körperregionen können eine Dicke von nur 0,1 $\mu \mathrm{m}$ haben. Ekto- und Entoderm der Calix- und Stielregion bestehen nur aus je einem Zelltyp; dadurch repräsentiert der Coronatenpolyp - mindestens für diese Körperregion und wahrscheinlich auch für andere Teile - den histologisch einfachsten Cnidariertyp. Das Coelenteron besitzt 4 schwach ausgebildete, kurze interradiale Septen, deren Filamente als spezielle Zellbänder auf der Innenseite der Mundscheibe, auf den Kanten der Septen und in aboraler Richtung auf der Wand des Coelenterons bis in den Stiel verlaufen. Das Periderm besteht aus der basalen Haftscheibe und der Röhre, die eine charakteristische Oberflächenstruktur aufweist. Die Wand der Röhre verdickt sich um etwa $0,6 \mu \mathrm{m}$ pro Tag und erreicht eine maximale Dicke von etwa $20 \mathrm{~mm}$. Ein experimentell gesetzter Defekt der Röhrenwand wird nicht in vollständiger Wanddicke ausgefüllt, vielmehr wird nur die Innenseite (der Boden) der Offnung durch eine vom Ektoderm neugebildete, strukturlose Peridermschicht verschlossen. Die zahnartigen hohlen Vorsprünge der inneren Röhrenwand werden gebildet, wenn eine Wanddicke
\end{abstract}


von $4 \mu \mathrm{m}$ erreicht ist. Die Zahnbildung geht in der Weise vor sich, daß sich der Weichkörper an begrenzten, im Querschnitt symmetrisch angeordneten Stellen von der Röhrenwand abhebt und daß die entstehenden Höhlungen der Körperwand nach außen Peridermsubstanz ausscheiden. Ein verdicktes Epidermisband auf der Außenseite des Kopfteils bildet in einer schwach ausgebildeten peripheren Rinne die äußere, mit der Skulptur versehene Schicht der Peridermwandung, die eine Dicke von etwa $4 \mu \mathrm{m}$ hat. Die sich kontinuierlich verdickende innere glatte Schicht der Röhrenwandung wird vom Ektoderm des Calix und des Stiels gebildet.

\section{INTRODUCTION}

Stephanoscyphus is the provisional generic name for the polypoid stage of the various genera of the scyphozoan order Coronatae. When the medusoid stage is known, the valid name becomes that of the medusa. Apart from the flower-like $S$. racemosus (Koмai 1935) the other polyps whether they are solitary or colonial, are much alike. They all live within a peridermal tube unlike the polyp of the order Cubomedusae and the scyphopolyps of the orders Semaeostomeae and Rhizostomeae where the periderm (perisarc) is absent or weak (Werner et al. 1971, Chapman 1966). The Stauromedusae are a mosaic of polypoid and medusoid features. Further research may show the necessity for raising the order Cubomedusae to the rank of class.

The microanatomy of the cubomedusan polyp has not been studied but the polyps of the Semacostomeae and Rhizostomeae are known from the works of several investigators (see GoHar \& EISAWY 1960 for references; also see Chapman 1966). For the Coronatae it is the less usual S. racemosus that is best known (Komar 1935).

ALLman (1874) was the first to study the microanatomy of a coronate polyp by means of dissection and viewing parts under the microscope. He found the ring sinus, and incorrectly guessed it opened by four inter-radial apertures to join four fictitious radial canals. His specimens must have been fixed with the mouth open because he definitely denies the existenc of an oral disk. Another more understandable error concerns the number of cell layers making up the medial wall of the ring sinus. He could make out one only and the reason for this is that the coelenteric lining of this region can be $0.1 \mu \mathrm{m}$ thick, much below the resolution of his technique.

Like Aliman (1874), Schulze (1877) noticed the internal tooth-like projections of the periderm. SchULzE corrected ALIMAN as to the oral disk but strangely he failed to find the ring sinus. On morphological grounds he was led to believe that this was a scyphopolyp whereas Allman wrongly classed it with the Hydrozoa.

Komar (1935) was the first to use sectioned material and despite his not narcotizing the specimens before Bourn fixation, his subsequent care in interpretation produced a clear microanatomical picture of $S$. racemosus. It is remarkable that at this late date, this rather different coronate polyp should be so better known microanatomically than the more numerous uniform species. Rakovec's (1953) paper includes several photographs of sections of $S$, mirabilis:

WERNER's (e. g. 1966, 1967a) recent works on coronate polyps contain diagrams illustrating the basic organization at a low power microscopic level.

With respect to total periderm replacement, WERNER $(1970 \mathrm{a}, \mathrm{b})$ found that the polyps of Nausithoë punctata and S. racemosus when stripped of their periderm could 
replace it after several weeks. A fragment of a solitary species, on the other hand, managed to envelop itself in a thin periderm but there was no regeneration of the polyp and it died after several months. Concerning repair of an experimental hole in the periderm, WERNER $(1966,1967 \mathrm{~b})$ used the solitary scyphopolyp of Atorella vanboeffeni. The natural sculpturing of the periderm has transverse and longitudinal markings but in a few days the hole is sealed by a smooth periderm unlike the sculptured original.

The taxonomy, biology, cnidome and detailed anatomical measurements of coronate scyphopolyps will be treated in a monograph by one of us (B. W.); the purpose of this communication is to describe the microanatomy of a solitary and a colonial species of the uniform type of coronate scyphopolyp. Observations on repair of the periderm are also described.

\section{MATERIALS AND METHODS}

The solitary Moroccan species (Stephanoscyphus sp. 6, WERNER 1970b) examined is as yet unnamed but will be described in the Monograph: a drawing from life is shown in Figure 1. The colonial species (Fig. 2) is Nausitbö̈ punctata Köllrker, 1853 (formerly S. mirabilis AlLmaN).

These are cultured in covered glass bowls at 15 and $20^{\circ} \mathrm{C}$ respectively and are fed regularly on Artemia and minced Mytilus.

The magnesium-sea water anaesthetic given by PANTIN (1960) is excellent but about $50 \mathrm{~min}$ are necessary before fixation is attempted.

For light microscopy the microanatomical techniques make use of a $4 \%$ formaldehyde-sea water fixative, benzene clearing, Tissumat (FISHER) embedding and staining by HARris' haematoxylin and alcoholic eosin, phosphotungstic acid haematoxylin (Thompson 1966) after a mercury mordant (saturated mercuric chloride for $2 \mathrm{~h}$ at $60^{\circ} \mathrm{C}$ ), and Masson's trichrome (PANTIN 1960) using Snngh's (1969) technique for the nuclear stain.

Elastic fibers are stained by ELDER \& OwENs' (1967) spirit blue method.

Whole mounts are stained with borax carmine or chlorazol black E (PANTIN 1960) and viewed with a polarizing microscope to visualize the muscle fibers.

The histochemical techniques used to study periderm repair are mercury-bromphenol blue (PEARSE 1960, second formula), silver methenamine (LILIIE 1965; GomoriBurtane method) and the periodic acid-Schiff reaction (Pearse 1960, Barger and DeLAMATER method with haemalum and orange $G$ ).

A thorough investigation by electron microscopy was not attempted; however, some regions of the polyp proving difficult to examine by light microscopy because of their minuteness were investigated after a one-hour fixation in $1 \%$ osmium tetroxide in sea water. The specimens were brought to $70 \%$ ethanol for storage for several days until they could be embedded in Taab resin or styrene-methacrylate (KuskrnA 1961).

Acetone hardened periderm is coated with gold-palladium and examined by a Cambridge Stereoscan scanning electron microscope.

Selective techniques to demonstrate the nervous system were not attempted. 


\section{RESULTS}

\section{Short description and terminology}

The polyp is comprised of the soft-body (properly called the coenosarc) within the periderm (properly called the perisarc).

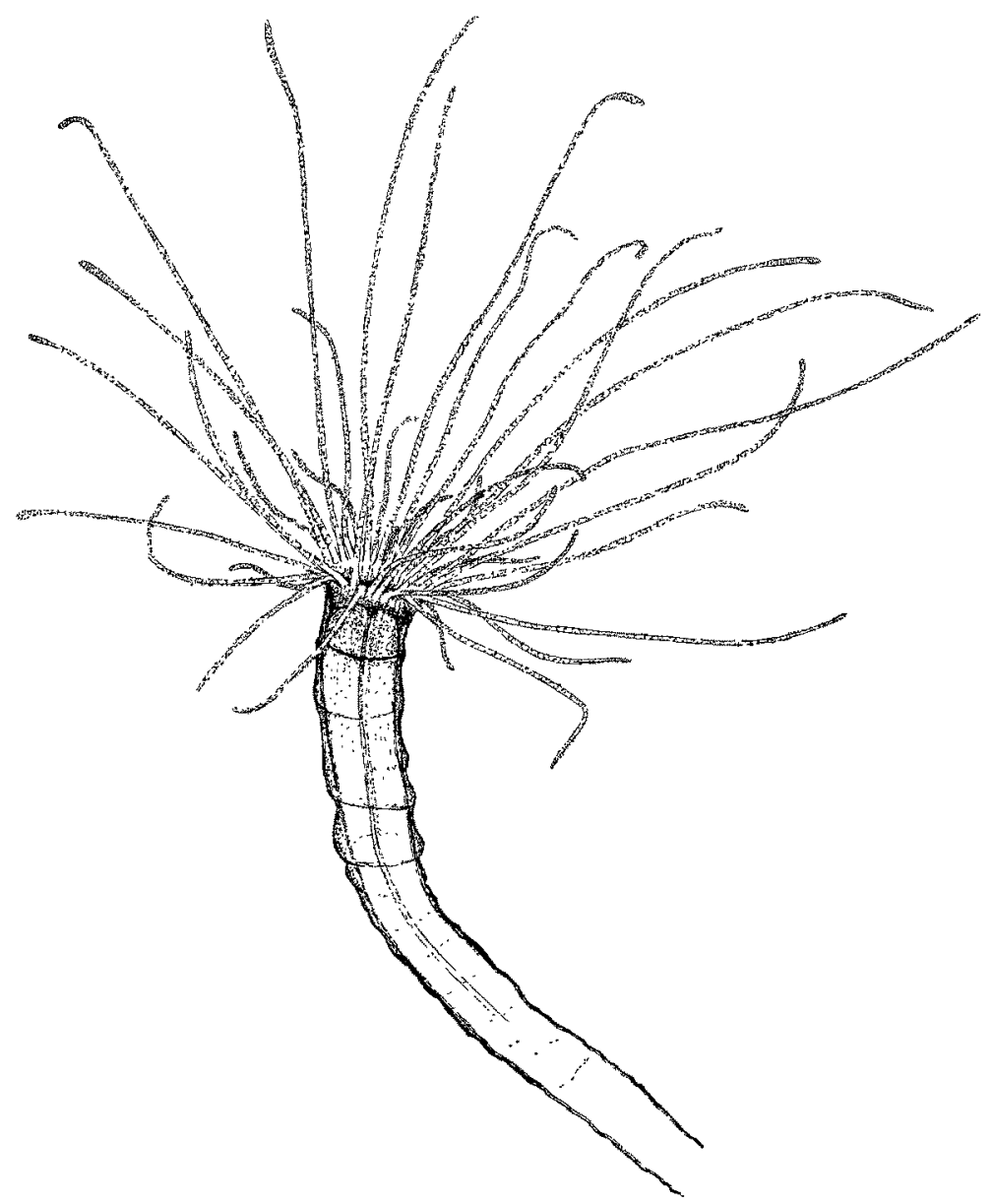

Fig. 1: Stephanoscyphus sp. 6, drawing from life of the oral end of this solitary polyp. (Drawn by F. HECKMANN)

The periderm is made up of an irregular low planoconvex basal disk (Fig. 32) containing irregular incomplete chambers lined by coenosarc. The sculptured tube (Fig. 34) widens orally from the basal disk. Many scyphopolyps have sets of internal projections occurring at intervals (Fig. 35). They are of variable shape in different species and vary even at different levels in any one species. Other authors have compared them with blunt rose thorns or a man's nose but we refer to them as "teeth". 
The tissues of the soft-body are the usual outer ectoderm and inner endoderm with a middle mesolamella layer. The species treated here have a round mouth leading into the coelenteron which contains four gastral flaments, inter-radial in position thus marking off four per-radial gastral pouches. In the oral end of the coclenteron the filaments are found on the free edge of short shallow septa.

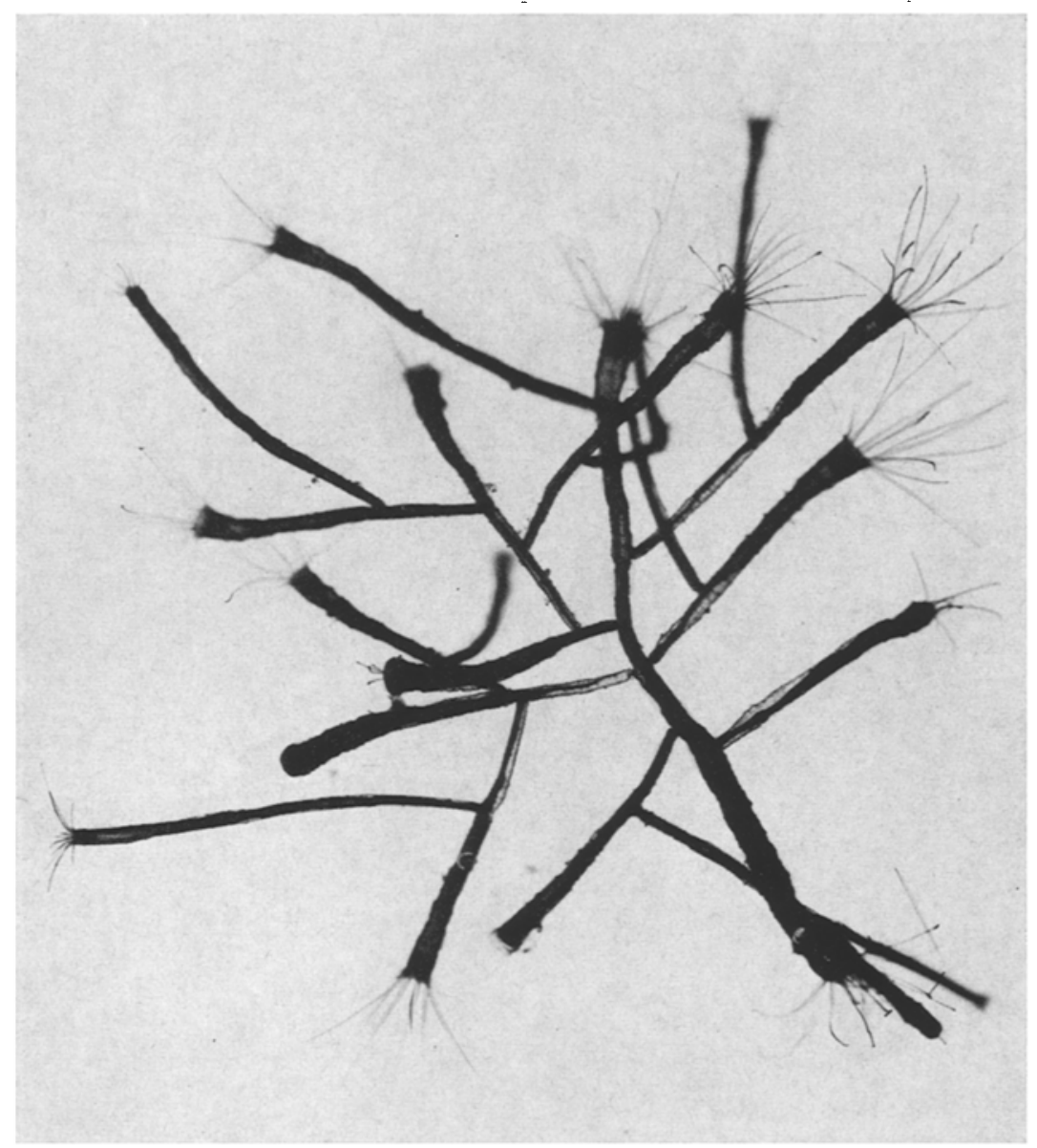

Fig. 2: Nausithoë punctata, a colonial species reared in the laboratory, photographed from life. (From WerNER 1970a)

The aboral end of the soft-body is here called the capitulum and in extended polyps extends beyond the periderm tube. More significantly its lateral ectoderm (collar) is different histologically from the ectoderm of the calyx and stalk which are the parts between the capitulum and basal disk. The calyx is between the capitulum and stalk and is the region that is transformed into ephyrae. The stalk has an endoderm which thickens with food reserves. Aurelia, a semaeostome polyp, shows the division 
between calyx and stalk more clearly even to the naked eye. In Aurelia the septa are only located in the calyx (CHAPMAN 1966).

The most oral end of the ectoderm of the calyx is thickened to give the junctional secretory band which forms the outer sculptured layer of the periderm (Figs. 3, 9, 10, 12).
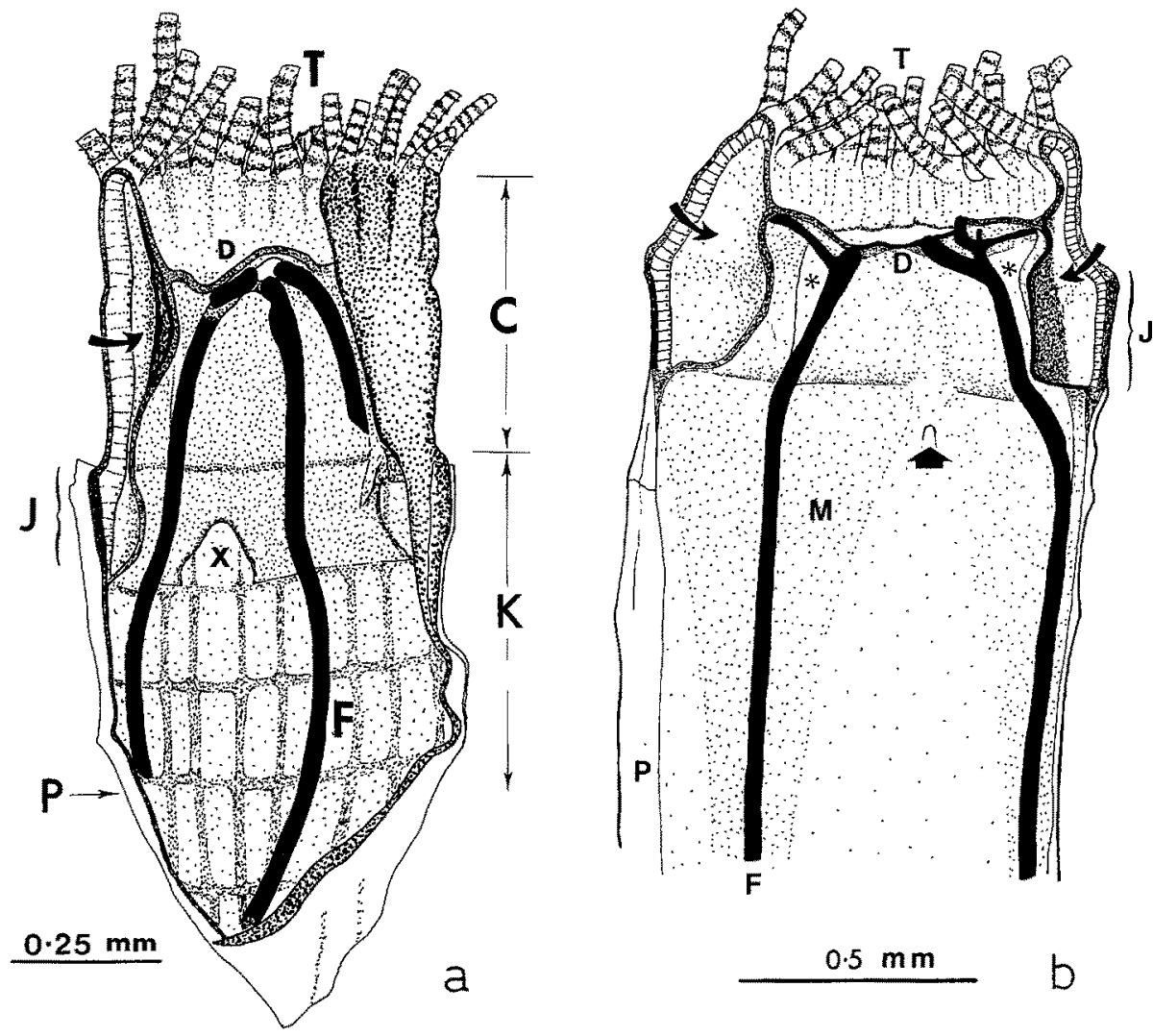

Fig. 3: (a) Dissection of the colonial species, Nausitboë punctata. $C$ capitulum; $D$ oral disk; $F$ gastral filaments almost meeting at the mouth; $J$ junctional secretory band; $K$ calyx; $P$ periderm; $T$ tentacles (cut short); $X$ opening between ring sinus and coelenteron. The arrow points into the ring sinus. (b) Dissection of the solitary species. Above $D$, oral disk; $F$ filament; $I$ junctional secretory band; $M$ muscle tube field with denser stipple; $P$ periderm; $I$ ' tentacles (cut short). The septa are marked by an *. Curved arrows lead into the ring sinus. The short broad arrow points to the small per-radial pore which opens into a short canal which opens into the ring sinus. Note how the oral end of the filament branches

Surmounting the capitulum are the tentacles and both together constitute the crown (hence the generic name). The central part of the capitulum is depressed and has an oral disk with mouth at the depression's bottom. Encircling the capitulum and the top part of the calyx internally is a ring sinus having four per-radial communications to the coelenteron. 
The nature of the two polyps may be appreciated from an inspection of Figures 1 and 2.

\section{Microanatomy}

The key to understanding the peculiarities of coronate polyp organization centres around the ring sinus and its relationship to the muscular system.
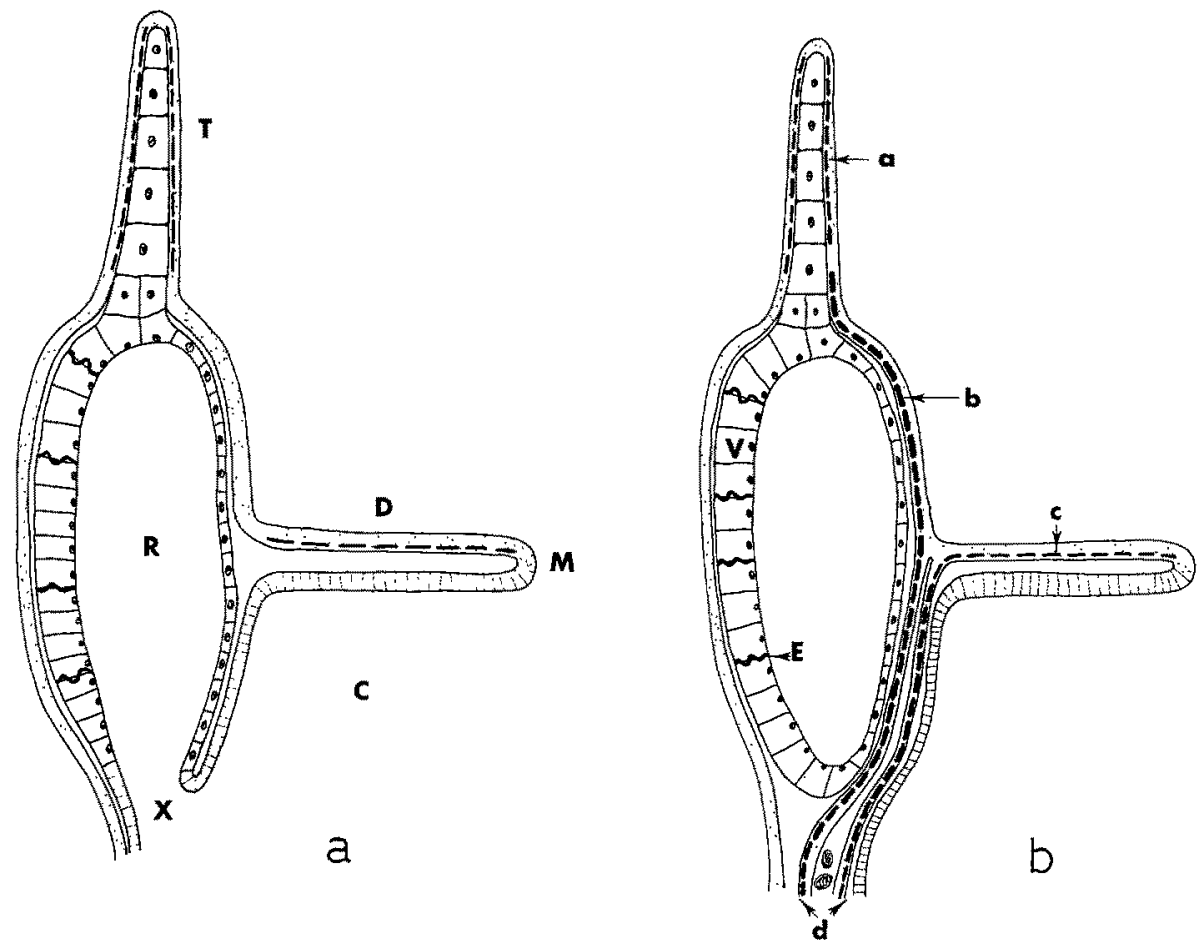

Fig. 4: (a) Diagram of a hemi-capitulum of a coronate polyp at the per-radius, longitudinal section. $C$ coelenteron; $D$ oral disk; $M$ mouth; $R$ ring sinus; $T$ tentacle; $X$ communication between coelenteron and ring sinus. (b) As in Figure 4 (a) but just to one side of an inter-radius (hence the gastral filament is not shown). $a$ thin tentacular musculature; $b$ thick musculature of medial ectodermal wall of the ring sinus: $c$ thin radial musculature of the oral disk; $d$ muscle tube showing two cnidoblasts: $E$ elastic fibers; $V$ vacuolated epithelium of the ring sinus with apical nuclei

\section{Capitulum}

When the capitulum is extended the sinus is rather slit-like (Fig. 3) with the endoderm lining a narrow roof surmounted by tentacles as well as lining the medial and lateral sinus walls which converge aborally. At four per-radial aboral points on the medial wall are connections (Figs. $3,4,5,10$ ) to the coelenteron: simple pores in the colonial species or short canals in the solitary species. The pore in the colonial species is 
vaulted with its base at the same level as the aboral edge of the ring sinus (Fig. 3a). In the solitary species the communication with the coelenteron is aboral to the ring sinus at the end of a short canal (Fig. 3b). One specimen was noted lacking this communication in one of the per-radi.

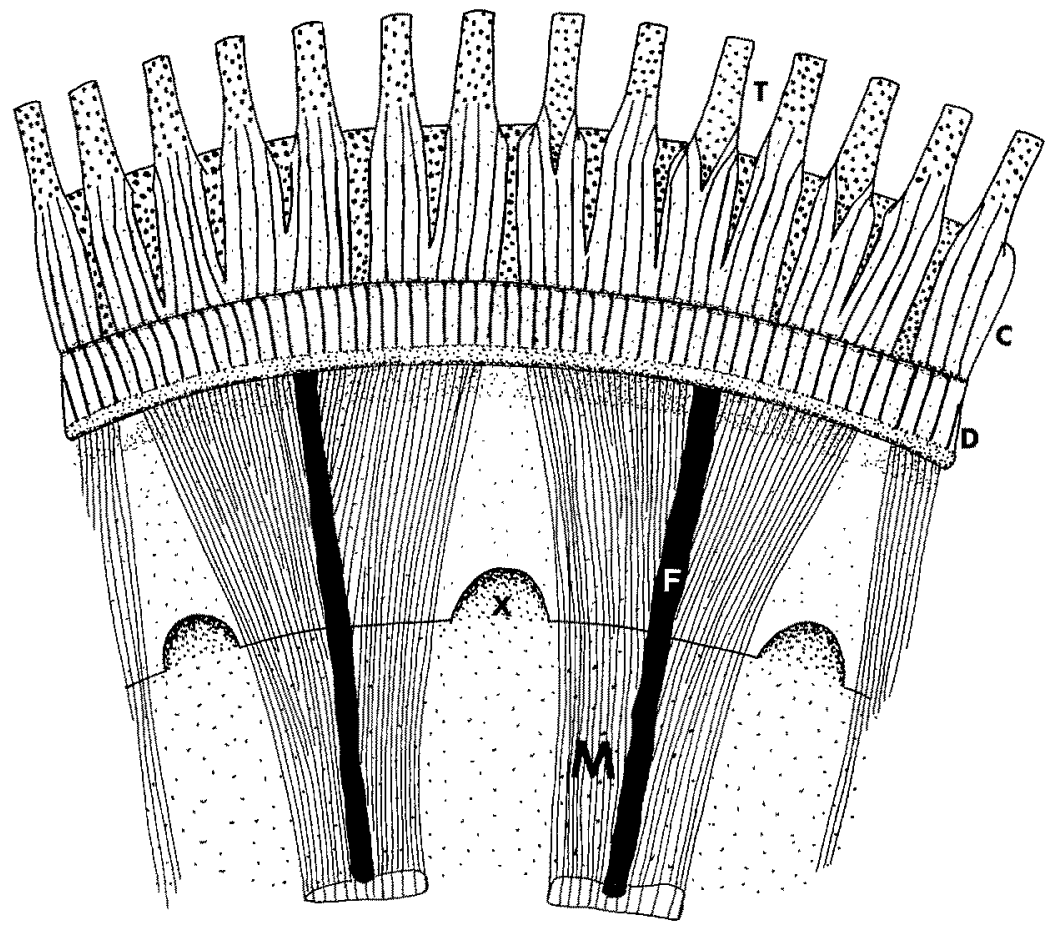

Fig, 5: Diagram of the oral end of a coronate polyp opened out to show the relationship of the muscular system to the rest of the polyp. Note how the thick myofibrils of the capitulum insert on the tentacles. $C$ capitulum; $D$ oral disk; $F$ gastral filament; $M$ muscle tube; $T$ tentacle; $X$ communication between coelenteron and ring sinus

The simple squamous lining of the medial wall is as thin as epithelia can become, i. e. $0.1 \mu \mathrm{m}$ (Fig. 9). The lining of the roof and lateral wall, on the other hand, is even more remarkable because of the tall simple columnar cells each of which has an apical inucleus and a vacuole taking up most of the cell volume (Figs. 4, 9, 10, 30). The vacuolated endodermal core cells of the tentacles are similar and can be in line with these sinus cells (Fig, 10).

Completing the strange features of this epithelium is a system of intercellular elastic fibers perpendicular to the surface (Figs. 4a, 23). These are noticed in large specimens of the solitary species and are readily demonstrated by ELDER \& OWEN's (1967) stain for invertebrate elastic fibers. Other methods such as xylidene ponceau in Masson's technique give sharp preparations but a confusion arises in the latter method because muscle fibers also stain orange. The proteinaceous elastics are about $1.3 \mu \mathrm{m}$ wide and taper to a point at each end. There are fewer elastics than vacuolated cells 
which are huge and measure $50 \mu \mathrm{m}$ in height by $20 \mu \mathrm{m}$ in width. Sometimes a few elastic fibers run a short distance into a tentacle.

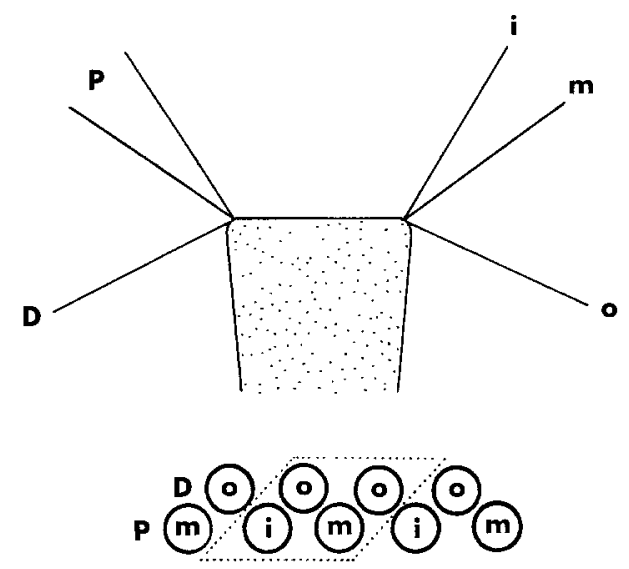

Fig. 6: Tentacle orientation in rypical coronate polyps. Above: diagrammatic side-view of capitulum showing the three tentacle orientations. Below: diagram of tentacle bases. $D$ distal (peripheral) row of tentacle bases; $P$ proximal (central) row of tentacles bases; $i$ inner row of tentacular tips; $m$ middle row; o outer row. A dotted parallelogram outlines a unit of tentacular bases

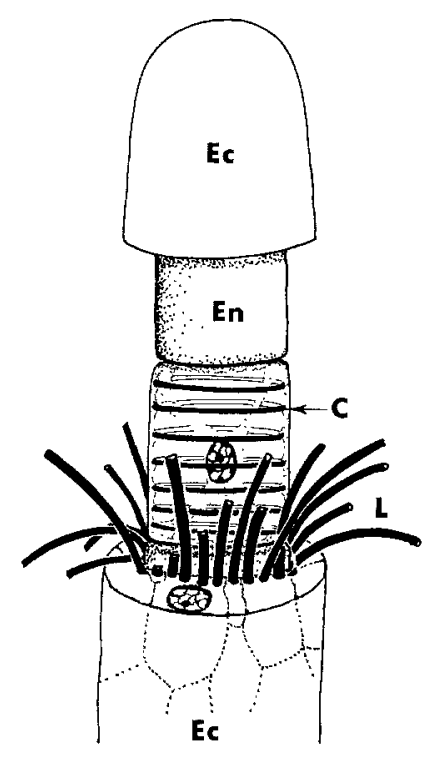

Fig. 7: Semi-diagrammatic representation of the tentacle tip. The mesolamella has been omitted. $C$ circular fibril; $E c$ ectoderm; $E n$ endoderm; $L$ longitudinal myofibrils splayed

Cellular debris in the form of $2-15 \mu \mathrm{m}$ globules may be found in the ring sinus but whether this is derived from ingested material or represents cast off cells from the polyp is unknown. 
In the extended state most of the ring sinus lies within the capitulum. The lateral ectoderm (collar) of the capitulum (Fig. 12) is made up mainly of agranular columnar cells $12 \mu \mathrm{m}$ wide in the solitary species and $18 \mu \mathrm{m}$ in the colonial one. The medial and lateral walls of the capitulum are flagellated and well armed with cnidocytes, mainly of the large variety. Whole mounts show the nuclei of small cells among the large ones (Fig. 12): perhaps they are sense cells.

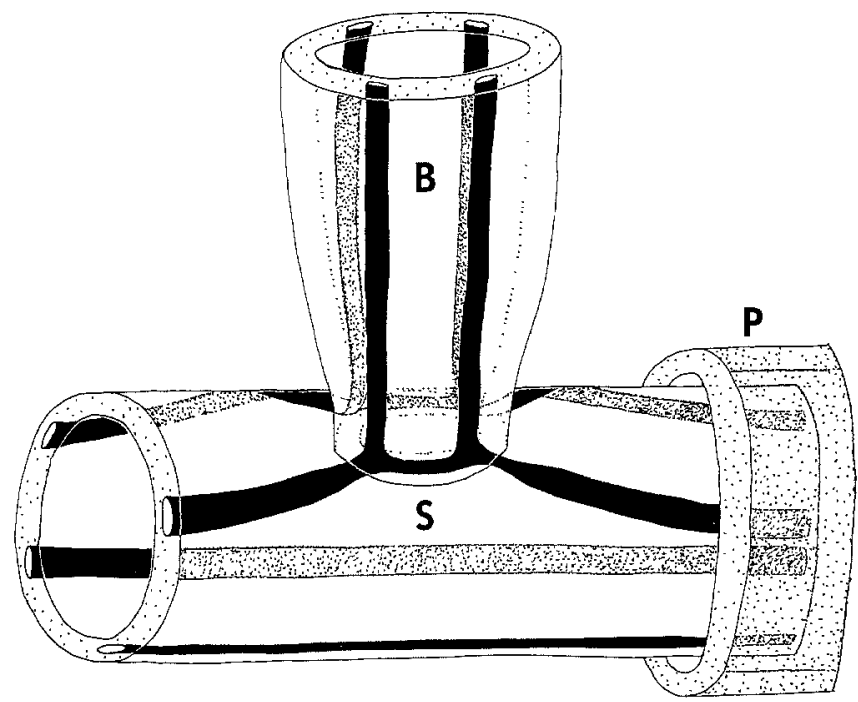

Fig. 8: The colonial species to show the relationship of the black muscle tubes of the stem $(S)$ to the branch $(B)$. Most of the periderm $(P)$ has been cut away. Two of the stem's muscle tubes converge to approach one another then send a process along the branch

The distal part of the sinus supports the tentacles then turns centrally and aborally to give the medial sinus wall. The oral disk is attached part way down the side of this wall which is coated with ectoderm; aboral to the oral disk's insertion, the sinus covering is endodermal since it is now in the coelenteron.

The ectoderm of the medial wall of the capitulum is a cuboid musculo-epithelium with the muscle fibers running longitudinally (Figs. 5, 11). At a tentacle this muscle

Fig. 9: Longitudinal section of the solitary species at one side of the capitulum which is slightly turned in. Note the similarity between the tentacular core cells and vacuolated sinus epithelium here and in Figure 10. Note how the junctional secretory band adheres to its cuticle. Araldite section stained with methylene blue-azur II. (250:1)

Fig. 10: Orientation like Figure 9 except that capitulum is extended. This per-radial section includes the communication between the coelenteron and ring sinus at the arrow. Solitary species; iron haematoxylin. $(130: 1)$

Fig. 11: Solitary species. Details of the musculature at the origin of the oral disk. Coarse muscle fibers from the tentacle enter the medial sinus wall and are closely associated with fine fibers (at arrow) from the oral disk thus forming the muscle tube. Orientation as in Figures 9 and 10 ; phosphotungstic acid haematoxylin $(700: 1)$. $C$ coelenteron; $D$ oral disk; $E$ region where the two epithelia are exceedingly thin; $J$ junctional secretory band; $M$ muscle tube; $P$ periderm; $R$ ring sinus; $T$ tentacle; $V$ vacuolated epithelium 


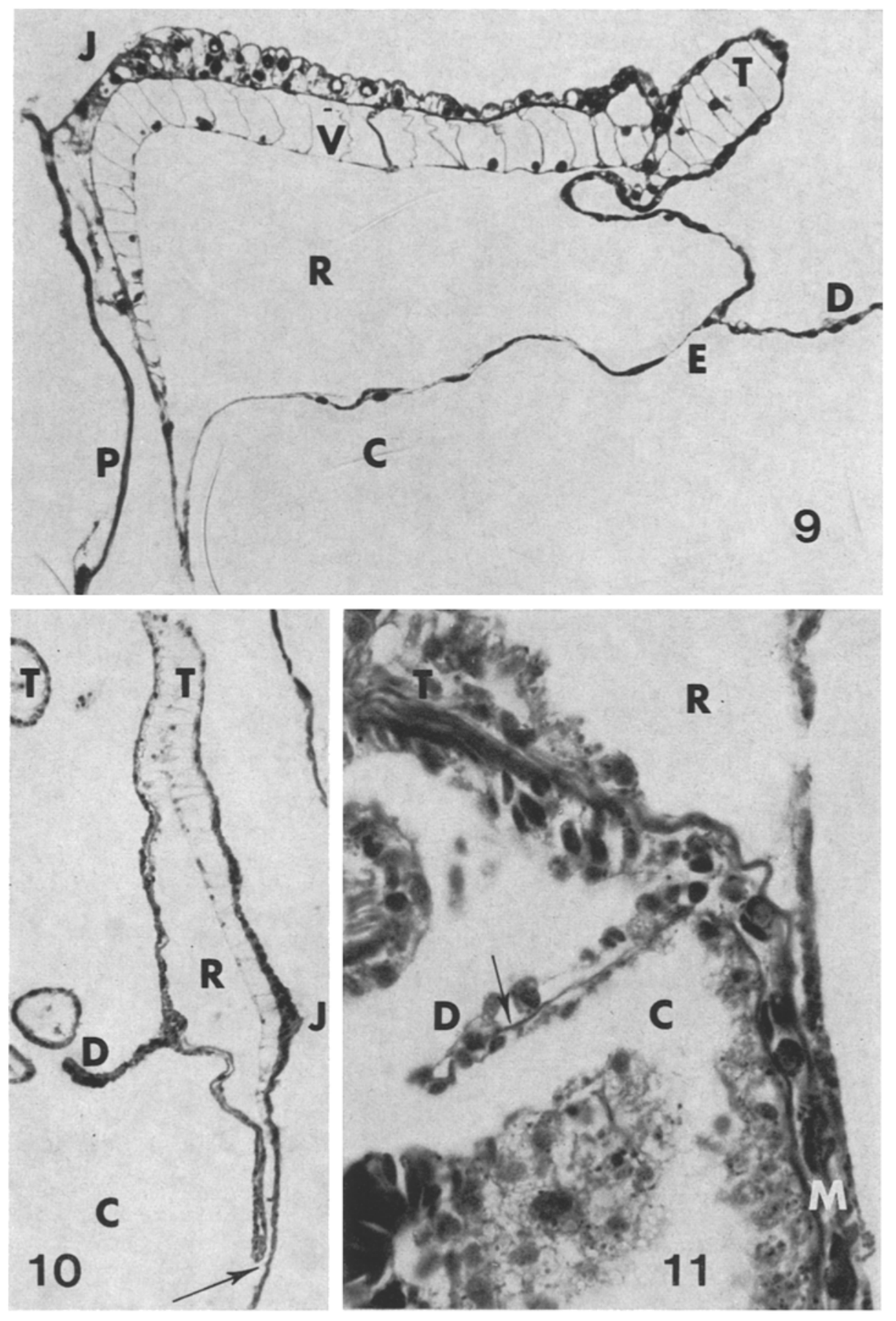


field sends a slip of musculo-epithelium a short distance along the tentacle or else the muscle field splits to send a slip a short distance along each side of a tentacle (Figs. 5, $11,22)$. Going in the opposite direction the musculo-epithelium continues on deep to the oral disk's attachment and the muscle fibers gently converge towards the nearest inter-radius (Figs. $4 b, 5,11$ ); the muscle fibers therefore diverge from the per-radial openings (Figs. $3 \mathrm{~b}, 5$ ). The radial musculature of the oral disk also dives aborally at the junction with the medial sinus wall so that the sinus wall bordering the coelenteron comes to have a double thickness of musculo-epithelium which forms a flattened straplike tube (Fig. 19) which continues aborally deep to the flament (Figs. 4b, 11). The confluence of the two muscle fields is sealed over by epithelium.

The cell layers between the ring sinus and central depression are therefore the ectodermal musculo-epithelium and the thin endodermal sinus lining; the layers between the ring sinus and the coelenteron are either two layers of endoderm just distal to and bordering a per-radial pore or else there is the coelenteric lining followed by two layers of musculo-epithelium before reaching the thin endodermal sinus lining.

\section{Calyx and Stalk}

The lumen of a muscle tube is lined by the muscular part of the musculo-epithelium (Fig. 31) and, now and then when the epithelial part is included in the section, a nucleus will be found towards the center of the lumen. Neurites are seen near the muscle fibers. The lumen contains a variable number of cnidoblasts at different stages of differentiation and large numbers of these cells may cause the strap-like tube (Fig. 27) to swell out in such a way that the tube becomes triangular in cross-section with the apex right below the filament (Fig. 20). This swelling has the effect of forming what looks like a broad septum (Fig. 21). Sometimes the muscle layer is thrown into folds directed to the muscle tube's center (Fig. 20). In the aboral regions the muscle fibers become slightly smaller in transverse section and are even diminished in number on the central side of the muscle tube.

CHAPMAN's (1966) observation that the muscle tube's fibers attach, here and there, to the teeth, is best forgotten because the tube continues aborally without attachment or interruption.

Fig. 12: Whole mount of oral end of the colonial species stained with chlorazol black E. The arrow points to a small cell type among the larger ones of the capitulum. The cells of the calyx are outlined by an agranular region $(240: 1)$

Fig. 13: Electron photomicrograph of a striated body in a muscle fiber. Styrene-methacrylate; colonial species. $(35000: 1)$

Fig. 14: Longitudinal section of the solitary species at the basal disk. The coenosarc is poorly preserved. Haematoxylin and eosin. $(170: 1)$

Fig. 15: Solitary species in an oral part of the calyx where the body wall is thin. Longitudinal section; haematoxylin and eosin. (480:1)

Fig. 16: As in Figure 15 but in the stalk where the body wall is thick. The discontinuity in the ectoderm is an artifact but the ellipsoidal granules are well demonstrated here. $(480: 1)$ Fig. 17: Colonial species in a region of the body wall showing a muscle tube with cnidoblasts. Notice how the ectodermal nuclei are twice as wide as those of the solitary species. Azan $(480: 1)$. C colenteron; junction between capitulum above and calyx below; $M$ muscle tube; $P$ periderm; $S$ stalk; $T$ tentacle 

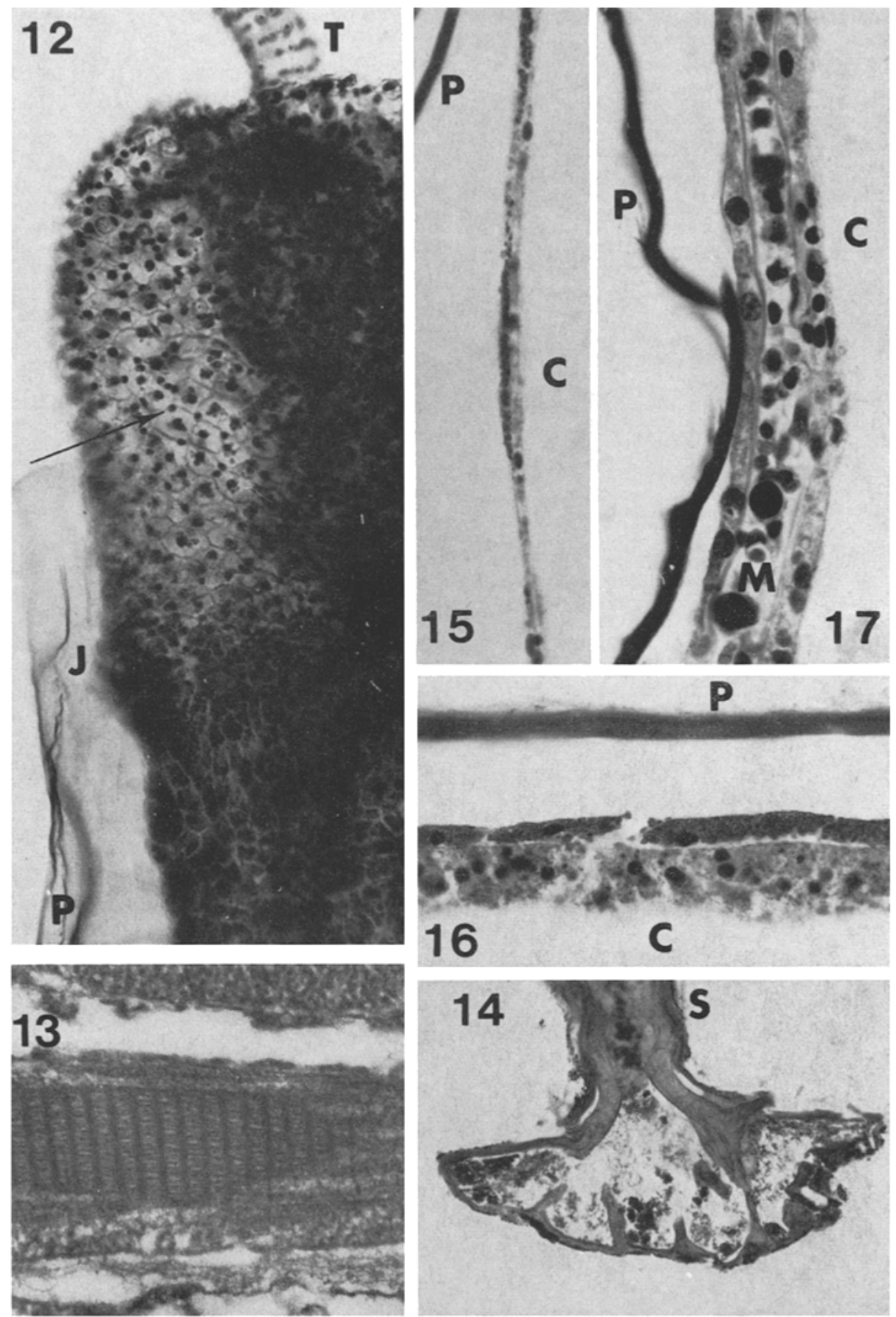
A strange feature is noted occasionally in some of these muscle fibers in the colonial species: a structure resembling a flagellar rootlet is found intercalated along the myofibril (Fig. 13). This striated body differs from a rootlet in that the crossbands in the striated body are symmetrical whereas this is not the case for rootlets (WESTFALL 1965).

Whole mounts and sections show the calyx-stalk ectoderm to be remarkably simple in being composed of one cell type, a polygonal squame. The ectoderm of the calyx-stalk which is always protected by the periderm lacks nematocysts. Although the branched species has a smaller polyp than the solitary one, its squamous cells and nuclei which measure $19 \mu \mathrm{m}$ and $10 \mu \mathrm{m}$ respectively (Fig. 17) are twice the diameter of those of the solitary species (Figs. 15, 16). Quite often these cells are packed with proteinaceous, eosinophilic ellipsoidal granules (Fig. 16) measuring $2.5 \times 1 \mu \mathrm{m}$; however, whole mounts show a $2 \mu \mathrm{m}$ zone free of granules between neighboring cells (Fig. 12).

Electron microscopy shows these granules to be enclosed by a membrane and to contain fine granular and sometimes filamentous material. A smaller $(0.2 \mu \mathrm{m})$ round, apical electron dense granule is encountered in the ectoderm of the whole polyp but is especially prominent at the site of cuticle deposition. The large type is PAS positive and the small one most likely corresponds to the argentaffin granules (see below). Although most granule types are membrane-bound, it is not so clear that this is the case here.

The cells of the ectoderm of the junctional secretory band are especially tall (ca $20 \mu \mathrm{m}$ ) in both species and often show a curious bend of the apical region towards the tentacular end of the polyp. The granules are numerous and of the same sort as in the rest of the calyx and stalk.

\section{Oral disk}

The oral disk is so thin and capable of dilating the mouth to such a degree that it can almost disappear. Dilatation is effected by a flagellated ectodermal musculo-epithelium having fine radial muscle fibers measuring $0.4 \mu \mathrm{m}$ in diameter in the solitary species. Although they join the muscle tube on its medial side, they do not extend along it very far because the muscle tube has its own special muscle fiber type.

A search for a circular sphincteric system of muscle fibers at the lip proved some-

Figs. 18-21: Transverse section of the filament and muscle tube at different levels in the polyp. Solitary species. Fig. 18. Oral disk. The filament is spread out and not associated with the muscle tube at this level. Note the thin ectoderm above the flagellated filament. Araldite section; methylene blue-azur II. $(640: 1)$

Fig. 19: Oral end of stalk. The filament is almost circular and has neither septum nor mesentery. Carmalum, orange G. $(440: 1)$

Fig. 20: Stalk region but filament not shown. The endoderm is thick due to absorption of food. The triangular muscle tube has some centrally directed folds of muscle (at arrow). Phosphotungstic acid-haematoxylin. $(780: 1)$

Fig. 21: Mid-stalk region. Sometimes the muscle tubes become bloated with cnidoblasts and this tends to spread out the filament as has happened in three cases here. Haematoxylin and eosin (150:1). $C$ coelenteron; $E$ ectoderm; $F$ fllament; $M$ muscle tube; $P$ periderm 

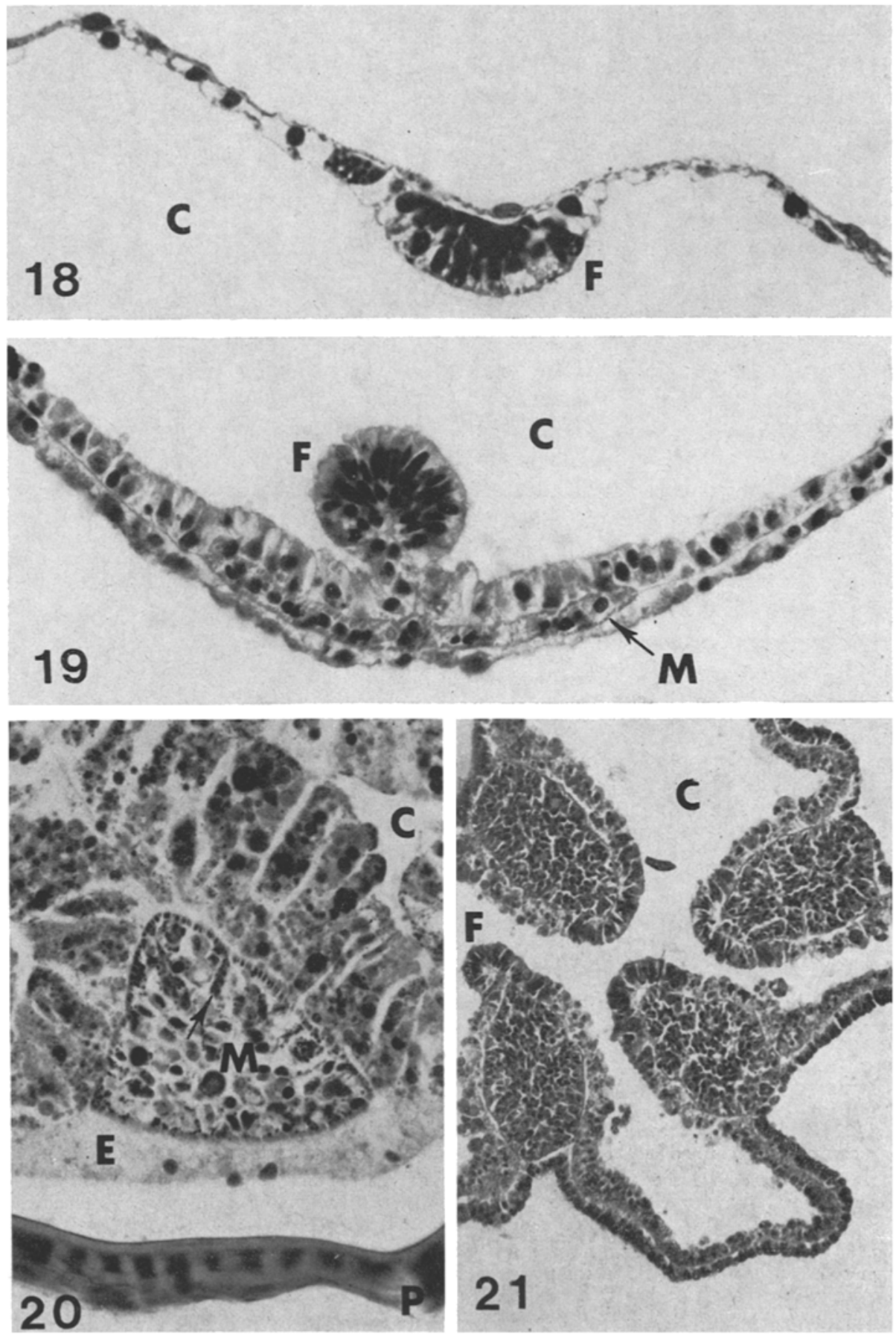
what inconclusive because of inferior preservation and the delicate nature of the fibers. The endoderm near the lip shows a hint of basal fibrous bundles that might be a contractile system for this delicate membrane.

The oral disk's endoderm is much like that of the neighboring coelenteric endoderm except that there are also a few granular cells present.

\section{Tentacles}

The tentacles are long and gently tapering although a slight terminal shortening may give a clubbing at the tip. The endodermal core (Fig. 10) consists of a single row of highly vacuolated cells except basally where more than one cell may be found in transverse sections. Iron haematoxylin shows a fine circular system of rings near the periphery of these cylindrical cells (Figs. 7, 29).

The tentacular ectoderm is mainly a flagellated musculo-epithelium with the fibers running longitudinally (Fig. 7), several myofibrils per cell. These fibers are about the same width as the radial disk fibers. Most preparations give the impression that the longitudinal tentacular fibers do not reach the tentacular base where, it will be recalled, other stouter fibers from the capitulum are found.

Cnidocyte bands completely or partly encircle the tentacle or else short irregular spirals are formed. The nematocysts are mainly of the small variety. Also present are a few granular cells whose granules are PAS positive.

One fairly extended tentacle was examined near its mid-point in transverse section by electron microscopy at high magnification. This was accomplished by taping the photographs together. No neurites were seen in this preparation.

Figure 6 shows the disposition of tentacles in a fully extended, undisturbed polyp. Inspection of the tentacular bases shows two rows, a proximal (nearer the polyp's central axis) and a distal; however, the tips show three rows: an inner, a middle and an outer. The basal distal row gives the outer tips and the basal proximal row gives the inner and middle tips in an alternate fashion. The idea of a tentacular unit is explained in the same Figure.

\section{Endoderm}

The endodermal regions comprise the tentacular core cells, the ring sinus lining and the coelenteron lining which, in turn, is comprised of gastral filaments, oral disk

Fig. 22: Colonial species; borax carmine stained whole mount of the medial aspect of the capitulum examined in polarized light with a quarter-wave retardation plate. $(440: 1)$

Fig. 23: Longitudinal section of the capitulum of the solitary species stained by Masson's technique and showing elastic fibers (at arrows) in the vacuolated epithelium. Note apical nuclei. $(330: 1)$

Fig. 24: Longitudinal section of the solitary species stained with Harris haemotoxylin and eosin. The experimental hole in the periderm is being repaired by a thin cuticle at the arrow. Note how the ectoderm has thickened in the repair region (140:1). F flament; $M$ muscle fbers; $P$ periderm; $R$ ring sinus; $T$ tentacle 

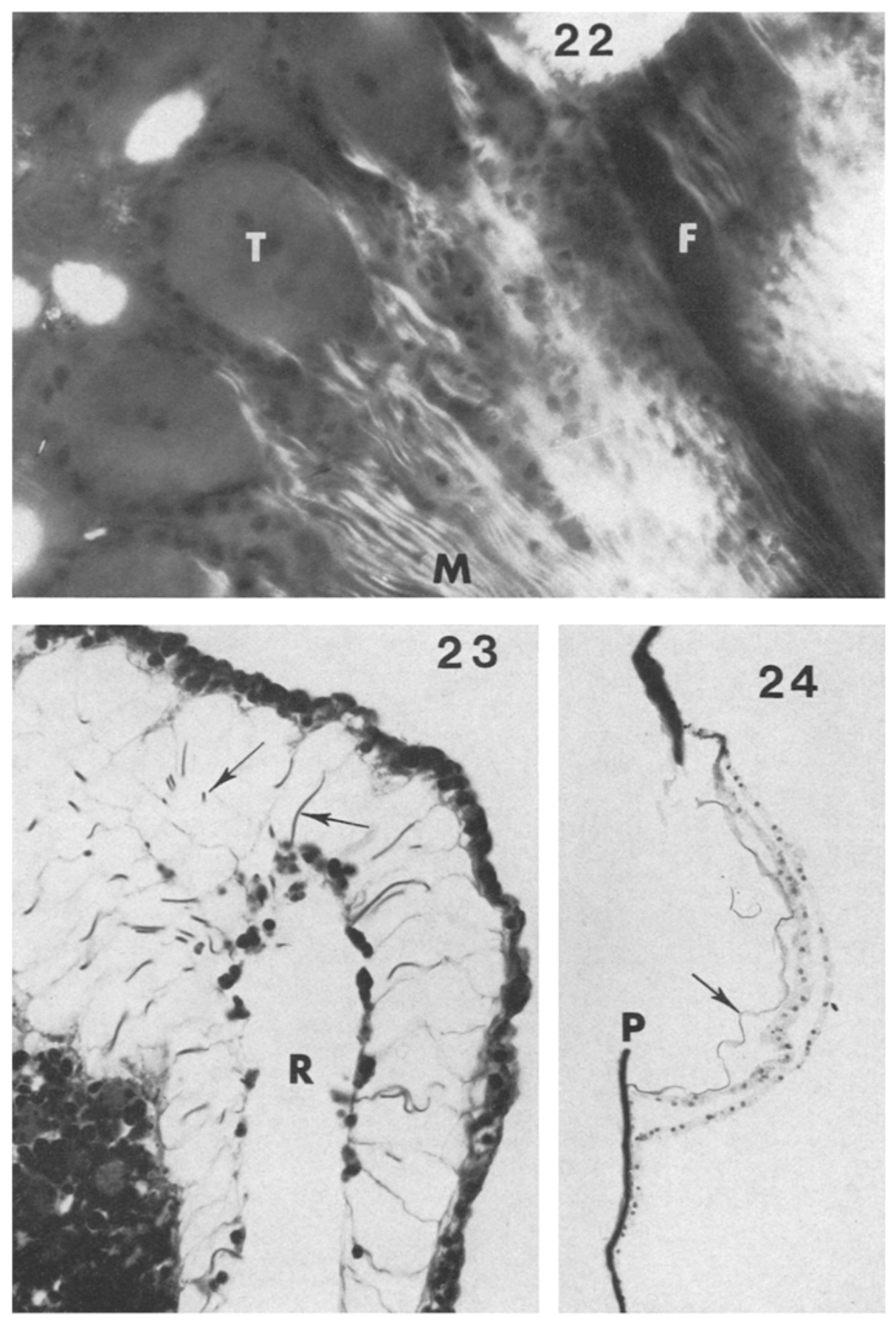
lining and the rest of the coelenteron lining which is now described under the label, absorptive epithelium.

Except for the occasional cnidoblasts, the cells of the absorptive epithelium are the same; however, those in the stalk region may look different when they are replete with ingested food. In the calyx region the cells are thin and measure less than 0.1 to $15 \mu \mathrm{m}$ while the ones in the stalk of the solitary species can measure $72 \mu \mathrm{m}$ in height by $7 \mu \mathrm{m}$ in width. In the latter case the cytoplasm is taken up by a varied assemblage of ingested matter (Fig. 20). Where the calyx-stalk is constricted between a ring of teeth, the ecto- and endoderm are much thinner.

As the polyp retracts the body wall thickens but is not thrown into transverse folds until extreme retraction occurs at which time folding commences.

Nuclear stains show a puzzling feature in the form of one or more $1 \mu \mathrm{m}$ wide cytoplasmic spheres in most endodermal and some ectodermal cells.

Once a coated vesicle of the type described by SLAUTTERBACK (1967) was found in an absorptive cell in the colonial species.

In the colonial species the filament reaches the mouth and is thickest in this region. As the mouth is opened the part of the filament attached to the oral disk becomes wavy (Fig. 3a) as does the calyx's filament when the polyp retracts. The oral end of the filament is more complex in the solitary species (Fig. 3b) because a branch of filament is sent radially along the disk and there may even be side branches towards the mouth.

The filament takes a different form at different levels of the polyp. On the oral disk the filament is a thick band of cells (Fig, 18) but as the filament leaves the disk, it rolls up to become an almost perfect circle in cross-section and is supplied with a short septum (Fig. 3b). Slightly more aborally this small septum is lost and the cylindrical filament is fused to the coelenteron (Fig. 19). Further aborally the filament gradually opens out again to become a narrow strip of thick special cells which become less definite as one procedes aborally in both species. Sometimes the underlying muscle tube, when it is swollen with cnidoblasts, may tend to flatten out the round filament because in certain transverse sections some of the four filaments may be either round or else spread out (Fig, 21).

In the stem of the colonial species the filament cells are represented in their characteristic position over the muscle tubes but they are rather few in number and by

Fig. 25: Solitary species near oral end showing formation of teeth. Note thin cuticle at arrow, Transverse section; haematoxylin and eosin. (260:1)

Fig. 26: Solitary species showing more advanced teeth. Note the thin cuticle bridging the tooth's lumen. Note bump forming at arrow. Transverse section; phosphotungstic acid haematoxylin. $(160: 1)$

Fig. 27: Wholemount of a longitudinal half of the colonial species stained with borax carmine and examined with polarized light using a quarter-wave retardation plate. Note the sharp delineation of the muscle tube running horizontally. $(160: 1)$

Fig. 28: Whole mount of the colonial species stained with borax carmine. Note the epithelial projection at the arrow. (140:1)

Fig. 29: Longitudinal section of a tentacle of the solitary species showing the longitudinal muscle fibers and a hint of the circular ones. Flemming without acetic; iron haematoxylin (700:1). $C$ coelenteron; $M$ muscle tube; $P$ periderm; $T i$ tooth at inter-radius; $T P$ tooth at per-radius 

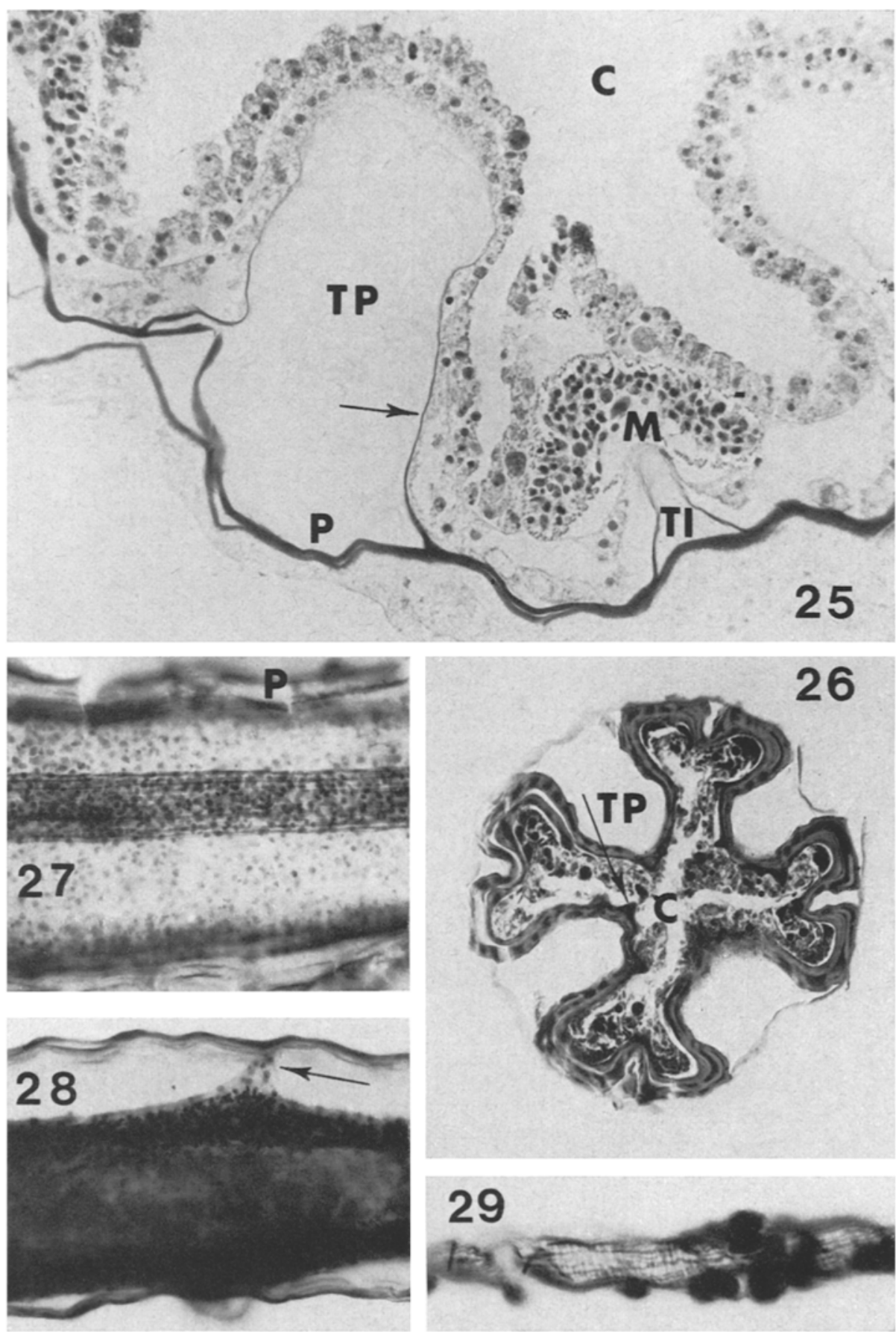
no means an obvious feature as they are in the oral region of a branch bearing a crown.

In the solitary species the rounded filament is about $55 \mu \mathrm{m}$ wide and is composed of tightly packed cells with radiating dark elongated nuclei.The most common cell is flagellated and the least common is a goblet-shaped cell with $0.8 \mu \mathrm{m}$ granules which are PAS positive and also contain a basic protein. Cnidoblasts make up the remainder of the cells here and the nematocysts are mainly of the larger variety.

Neurite bundles can be found in the filament near the mesolamella (Fig. 33).

\section{Mesolamella}

Usually this intermediate layer is very thin ( $0.1 \mu \mathrm{m}$ thick) and in some cases will stain with the PAS technique. In some places, e. g. the base of tentacles and near the gastral filaments, the mesolamella may be several micrometers thick. It is non-cellular and the fibrils are the fine unbanded probably collagenous variety.

\section{Neurites}

The various regions of the polyp were not searched methodically for neurites using the electron microscope but the impression from a cursory survey is that there are fewer neurites than in other cnidarians. The approximately $0.3 \mu \mathrm{m}$ wide neurites of the muscle tubes and filaments (Fig. 33) contain neurotubules and granular vesicles.

\section{Myofibrils}

The discrete myofbrils are the $0.4 \mu \mathrm{m}$ wide radial ones of the oral disk and longitudinal ones of the tentacles and also the 1-2 $\mu \mathrm{m}$ ones of the capitulum, tentacle bases and muscle tubes (solitary species).

A more doubtful, possibly contractile, system is found in the disk's sphincter, lateral ectodermal wall of the capitulum and as rings in the tentacular core cells. Even the thin cytoplasmic rim of the vacuolated cells of the ring sinus has a fibrous appearance. These indistinct filaments are about $7 \mu \mathrm{m}$ wide and are imperfectly aligned.

Figs. 30, 31, 33: Transmission electron microscopy of the solitary species. Taab resin. Fig. 30: Radial section of the capitulum showing a cell from the vacuolated epithelium. The nucleus is less apical than usual perhaps because of an autophagosome-like body. $(3700: 1)$

Fig. 31: Transverse section of the calyx region showing some muscle fibers of the muscle tube. $(13000: 1)$

Fig. 32: Scanning electron microscopy of the basal disk and stalk. Disk is about $400 \mu \mathrm{m}$ wide Fig. 33: Transverse section of a filament showing a bundle of neurites containing neurotubules $(32000: 1)$. $A$ artifact space on ectodermal side; $C$ view into chamber of basal disk through a break; $D$ basal disk; $M$ muscle fiber with granular vesicles; $R$ ring sinus; $S$ stalk periderm; $\checkmark$ vacuole 

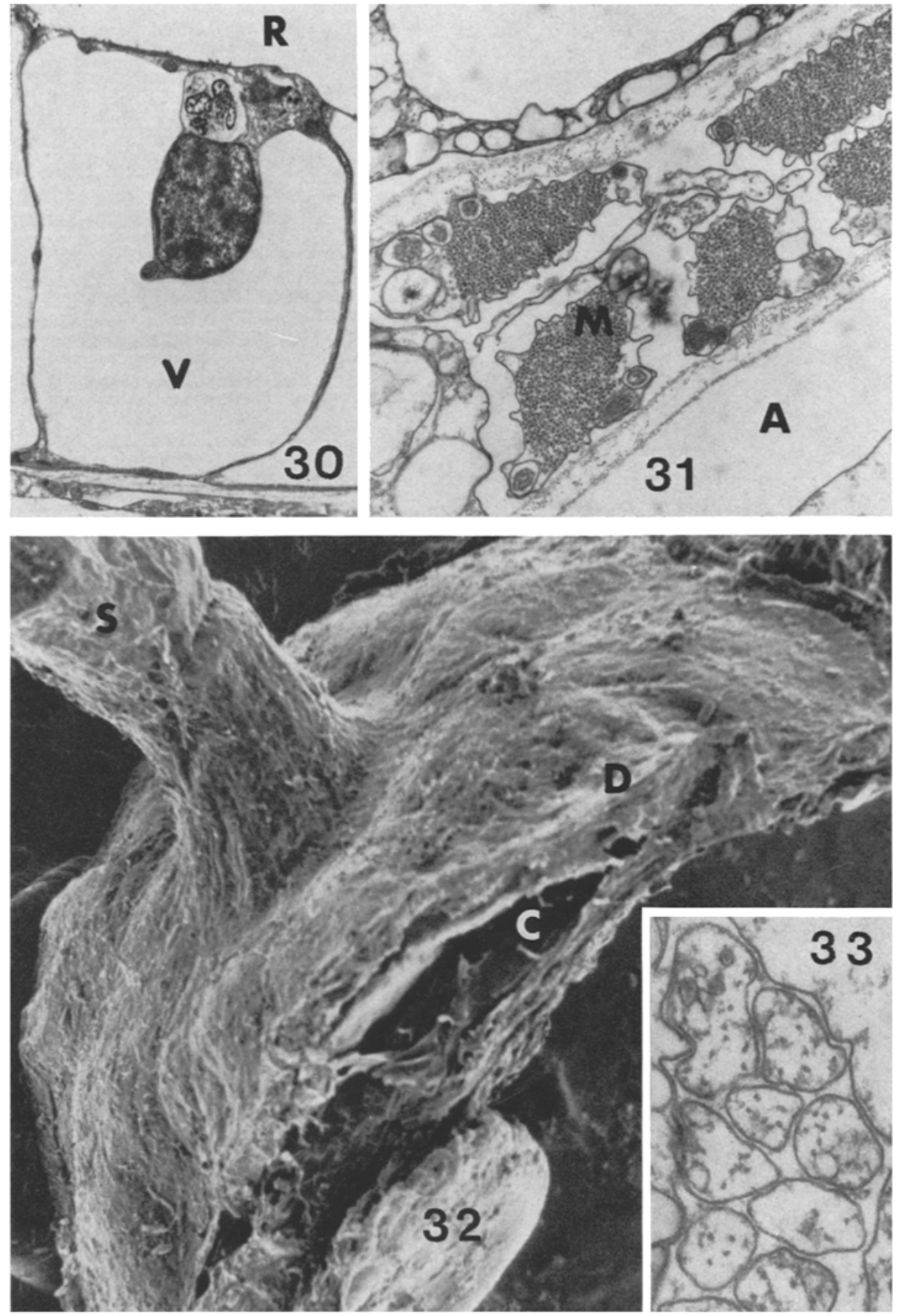


\section{Special features of the colonial species}

A seldom encountered feature in the colonial species is an ectodermal process which juts out to make contact with the periderm of a branch (Fig. 28). This might represent in some cases the manner in which a new branch is initiated.

The relationship of the muscle tubes between a branch and stem in the colonial species is as follows: two neighboring muscle tubes of a stem bend slightly to one another then each sends two muscle tubes to the branch (Fig. 8).

\section{Formation of the teeth in the solitary species}

The sets of teeth are formed at fairly regular intervals sometime after a new level of sculptured periderm has been laid down orally. Segments from this oral region were examined in transverse section in order to determine the manner of tooth formation. From Figure 25 it can be seen that there is a $4 \mu \mathrm{m}$ rim of periderm with an inner delicate cuticular lining to an invagination of the soft-body wall. The interpretation put on this is that the body wall first secretes a $4 \mu \mathrm{m}$ sheet of periderm then at four large per-radial spots and four small inter-radial spots the soft-body wall invaginates. The time it takes to invaginate is not known but presumably the ectodermal secretion of cuticle is not significantly delayed except slightly at the very pit of the invagination. After invagination about $16 \mu \mathrm{m}$ more of periderm are secreted therefore giving a wall thickness of $20 \mu \mathrm{m}$ and tooth thickness of $16 \mu \mathrm{m}$ (Fig. 26).

The space between teeth in a set becomes narrower with age as more cuticular material is laid down internally (Figs. 35 and 36).

\section{Nature and growth of the periderm tube}

Two specimens of the solitary species were sectioned transversely and serially at $10 \mu \mathrm{m}$ and measurements were made of periderm thickness at different levels. In transverse section the inside of the tube is round but on the outside, because of the sculpturing, the margin is scalloped. Measurements of periderm thidkness were always made radially through a depression in the scalloping.

One specimen was $22.95 \mathrm{~mm}$ long. The inside diameter was about $1.00 \mathrm{~mm}$ at the oral end and tapered to about $45 \mu \mathrm{m}$ near the pedal disk. The periderm thickness

Figs. 34-36: Scanning electron microscopy of the periderm of the solitary species. Fig. 34: Side view showing the sculpturing. The white flaments are probably some sort of microorganism. About $200 \mu \mathrm{m}$ wide

Fig. 35: Dissection viewing the oral end of a set of teeth. About $650 \mu \mathrm{m}$ wide

Fig, 36: Dissection viewing the aboral end of a different set of teeth. Note the hole $(H)$ because the periderm is thin at a tooth's base. About $350 \mu \mathrm{m}$ wide

Fig. 37: Transmission electron microscopy of the periderm of the solitary species cut longitudinally. The thin loosely textured lamellae show periodic material bridging the gap between lamellae. Taab resin. $(50000 ; 1)$ 

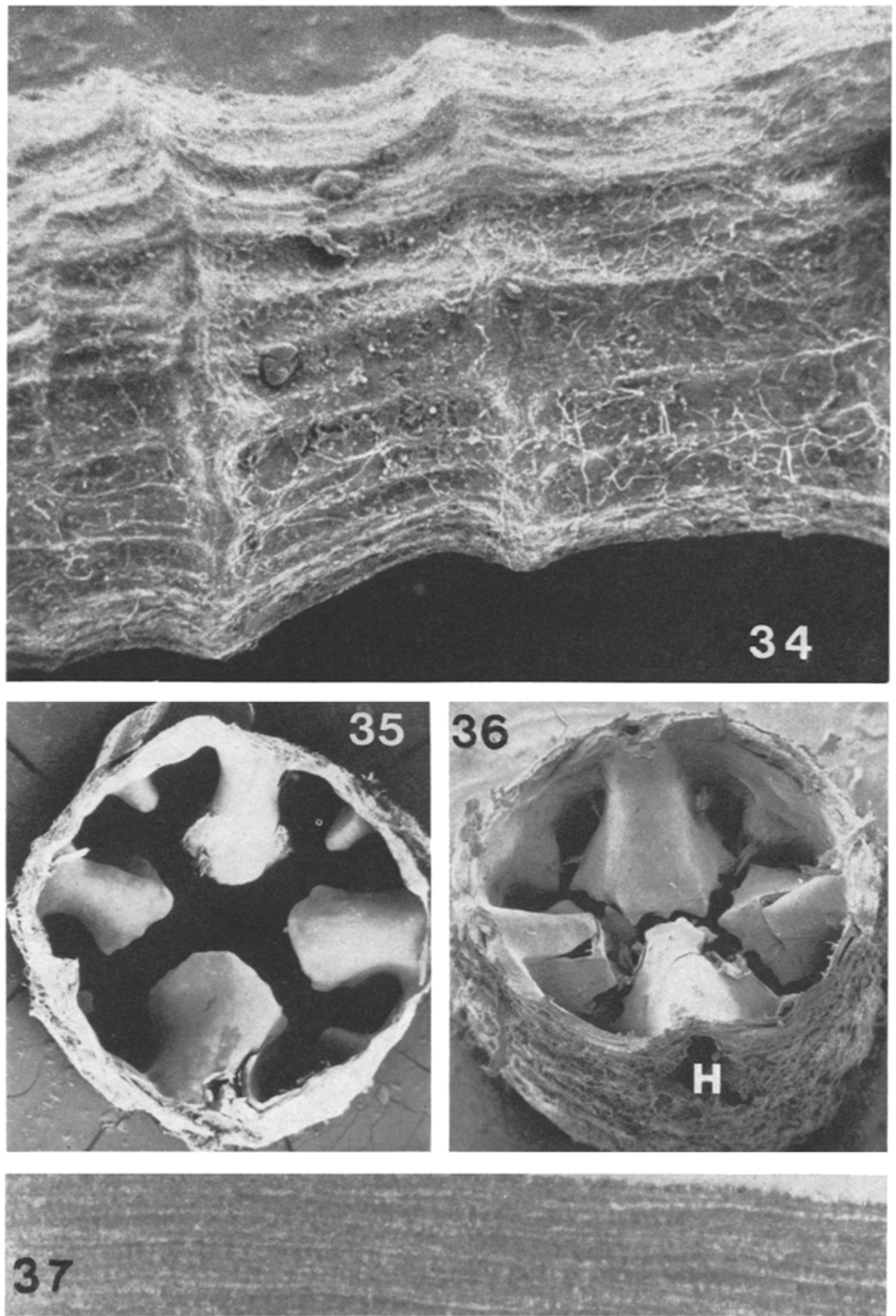
narrowed in the opposite direction but not as a gentle taper. Near the basal disk the thickness was $20 \mu \mathrm{m}$ and continued on the same length to about one quarter of the tube's length. From here over the remaining three quarters, the thickness tapered to $2 \mu \mathrm{m}$ at a level of $100 \mu \mathrm{m}$ from the oral end.

Another specimen was observed also having a maximum thickness of about $20 \mu \mathrm{m}$ but this time this full thickness was only about $1 \mathrm{~mm}$ from the oral end in the $8.2 \mathrm{~mm}$ long polyp.

The stem of the colonial species (which gives polyp-bearing branches) has a lumen which becomes rather constricted by new loosely textured, separated peridermal layers.

The periderm is made of chitin (CHAPMAN 1966). It is so soft that the tube can be squeezed together but will return undamaged to its former state. Transmission electron microscopy (Fig. 37) shows thin (12 nm) lamellae separated by about the same distance but bridged at $8 \mathrm{~nm}$ intervals by $14 \mathrm{~nm}$ wide processes whose shape was not determined.

The basal disk of the solitary species is made up of a dome, platform and irregular incomplete internal partitions all of which do not become as thick as the neighboring periderm tube (Fig. 14, 32). Preservation of the soft tissues was too poor to allow a detailed description.

\section{Repair of hole in periderm}

Fine forceps were used to make a minute hole in the periderm near the oral end. Specimens were narcotized and fixed after 1,2,3 and 6 days in order to follow the process of repair.

Tissumat sections were stained with haemotoxylin and eosin in order to detect such features as changes in epithelial thickness, in the nuclei, in the cytoplasmic granules, and in the secreted cuticle as compared to neighboring intact regions.

Histochemical tests were also used to detect chemical differences. The mercury bromphenol blue method is a somewhat uncritical method for protein, the periodic acid-Schiff technique tests for non-acidic carbohydrates and the silver methenamine technique is a rough indicator for reducing phenolic compounds. Since cnidarian peridermal is often a tanned protein-chitin complex, these histochemical tests are appropriate. As it turned out, the histochemical tests showed no consistent difference between the two regions. The apical granulation is rather variable either in intact or experimental regions and usually it is much the same in both places.

The cosinophilic granular matter gives a positive reaction for the mercury-bromphenol blue test but the PAS and silver methenamine tests were negative. Another finer sparser granule type is shown by silver methenamine which also colors the periderm. The hole does not seem to affect the underlying endoderm but the ectoderm is induced to treble in thickness and the nuclei become rounder. The cuticle over the hole is often adherent to the ectoderm.

The experimental hole is not filled in; however, the bottom of the hole (i. e. next to the ectoderm) is covered over by a cuticle (Fig. 24). This is not surprising because at the oral end of the polyp, the periderm in a normal polyp is being secreted and this 
covering layer for the bottom would have been secreted anyway. About $0.6 \mu \mathrm{m}$ per day of cuticular material is added to the hole's bottom.

\section{DISCUSSION}

\section{Comparative anatomy}

It would be premature to make a detailed comparison of scyphopolyps until the microanatomy of the cubopolyp (WERNER et al., 1971) has been described and until a greater understanding of coronate scyphopolyp organization is attained through a study of regeneration and normal development. Also a proper study of the endoderm requires a histochemical approach as was so successfully achieved by BouLLON (1966) for hydropolyps.

However several comparative features may be mentioned. At the histological level of organization, the polyps studied here are the simplest of all cnidarian polyps. Except for the filaments, the calyx-stalk body wall has only one cell type in each of the ecto- and endoderm-even nematocysts are absent from this ectoderm. With a peridermal covering this absence is appropriate. tubes.

Like in other scyphopolyps, cnidoblasts are found in the lumen of the muscle

The septa in the usual coronate polyps are poorly developed but $S$. racemosus (Komar 1935) has definite ones.

The intermediate layer is of the thin mesolamella type typical of hydropolyps and most unlike the mesoglea in other described scyphopolyps.

Semaeostome scyphopolyps have a histologically well defined scyphopharynx but the coronates lack this.

\section{Functional morphology}

When epithelia are compressed in one direction parallel to the surface they may react like paper and immediately start to fold or like an already stretched rubber membrane, they will become thicker without folding until the rubbery tension is relieved and then folding will occur. The body wall of the calyx region of the usual coronate polyps behave in the elastic manner. In Aurelia (Chapman 1966), on the other hand, the body wall behaves differently: the ectoderm behaves as the stretched rubber membrane whereas the endoderm immediately folds like paper.

In Stepbanoscypbus slight irritation of the capitulum results in shortening of the tentacles and turning in of the tentacular crown because of the shortening of the muscle field on the medial wall of the capitulum. Further stimulation causes shortening of the muscle tubes thus retracting the oral parts into the peridermal tube. The reextension mechanism is not all that clear. The elasticity of the deformed calyx-stalk epithelia and the coelenteric pressure caused by the filaments' flagella might be involved in bringing the capitulum to the tube's rim. Opening out of the capitulum is prob- 
ably caused by the turgid thick epithelium of the ring sinus. Assisting the vacuolated cells are the elastic fibers which would be stretched when the capitulum is turned in: when the muscles responsible for the turning in relax, the shortening elastics would act to sustain a high turgor in this epithelium.

During defecation the capitulum is hyper-extended laterally. Once again this is supposition but perhaps the muscle field of the medial wall of the capitulum relaxes even further allowing hyper-extension. Perhaps the vague lateral longitudinal muscle field on the capitulum helps account for extension and hyper-extension. It may be recalled that the vacuolated sinus cells are in line with similar ones in the tentacle and this might explain why the nuclei of the former type are apical, for this nuclear location is most uncharacteristic of epithelial cells. The per-radial holes allow water to leave the sinus when the capitulum is retracted and compressed.

The nature of the fibril rings in the tentacular core cells requires further study. They were seen by Schulze (1877) in the colonial species and a similar system was described for Aurelia by Friedemann (1902). Chapman (1970) gives reasons for doubting their contractility.

Animals requiring greater muscular strength in certain body regions usually increase the number of similarly sized muscle fibers per unit volume; here the number stays almost constant and greater strength is achieved by using larger fibers.

The absence of neurites about mid-way along a tentacle needs some explanation. The easiest way out is to invoke neuroid conduction, a method used by many cnidarians (MACKIE 1970); however, the behavior of these tentacles (CHAPMAN unpublished) is as complex as Aurelia's thus casting doubt on this restricted physiological phenomenon as the sole explanation.

\section{Some cytological features}

The striated body found in the muscle fibers of the stem of the colonial species is a mystery. BOULIGAND (1968) found a very similar body in an extracellular location next to the horny axis of a sea fan. Perhaps it represents the remains of a degenerated muscle fibers in the sea fan.

The intercellular intraepithelial unbranched elastic fibers are quite unlike any other elastic fibers as far as we are aware and, as is usual for cnidarians, the are undoubtedly formed by the neighboring epithelial cells and not by connective tissue fibroblasts which are lacking in this type of polyp.

The thin epithelia $(<0.1 \mu \mathrm{m})$ are found at the medial endodermal wall of the ring sinus (both layers) and in the oral end of the calyx (once again both epithelia). Such thin epithelia are found in places requiring a minimal diffusion barrier such as the lining of the mammalian lung but such a requirement is unnecessary in these polyps.

Scyphistomas have rivet-shaped desmocytes in their base (CHAPMAN 1969) but coronate polyps lack desmocytes of any type. 
The peridermal tube and teeth

The functional significance of teeth is unknown and perhaps they are some sort of vestige. Whatever their nature they are not a necessity because there are species lacking this feature. Teeth would, in fact, seem more of a liability because the soft-body becomes so constricted here. The Monograph will discuss the nature of teeth in detail.

The periderm thickens to about $20 \mu \mathrm{m}$ before it stops. The earliest peridermal tube is sufficiently wide that the subsequent internal cuticular layers do not choke off the stalk at the base.

The junctional secretory band, the sculptured thin outer layer of periderm and the thick inner smooth layer all seem to be related in the following manner which is an elaboration of WERNER's earlier explanation (1967b). The thick junctional secretory band has the same width as the repeating segmental peridermal levels and so we infer that this band secretes the 3-4 $\mu \mathrm{m}$ sculptured outer layer of the periderm. Fusion between band and periderm is often observed (Fig. 9). The polyp is then envisaged as lengthening so that the newest periderm segment is now opposite the thinner part of the calyx ectoderm. The calyx and oral end of the stalk too are capable of secreting periderm; however, this periderm layer is not sculptured but is, instead, smooth. This explains why a repaired hole is covered over with smooth periderm (Werner 1966). Also explained is the $4 \mu \mathrm{m}$ periderm layer at the base of a tooth because it seems that soon after the thin sculptured layer is laid down, invagination of the soft-body occurs with subsequent secretion of the smooth thick layer.

Therefore the periderm has two layers: an outer thin sculptured layer secreted by the junctional secretory band; and a much thicker smooth layer secreted by the calyx and stalk. Transverse sections through the junctional secretory band unaccountably did not show a corresponding configuration which could explain the sculpturing.

\section{SUMMARY}

1. A solitary and a branched (colonial) species of Stephanoscyphus belonging to the scyphozoan order Coronatae were studied by means of histochemistry, light microscopy and by transmission and scanning electron microscopy.

2. Coronate polyps are unlike all other cnidarian polyps in having a ring sinus in the oral end with four per-radial openings to the coelenteron.

3. The lining of the lateral wall of the ring sinus is remarkable in that the cells are so large, most of the cytoplasm is taken up by a large vacuole, the nucleus is apical and between some of the cells are unbranched elastic fibers aligned at right angles to the epithelial surface.

4. The organization of the muscular system is also peculiar because much of it is related to the ring sinus. Musculo-epithelia from the oral disk and medial sinus wall meet and continue aborally as four flattened tubular retractors containing cnidoblasts.

5. In the colonial species some muscle fbers contain structures resembling ciliary rootlets. 
6. The intermediate layer is of the mesolamella type.

7. The tentacles have longitudinal ectodermal epithelio-muscular cells and a solid core composed of a single line of vacuolated endodermal cells which contain peripheral fibrous rings.

8. The medial sinus wall and the epithelia of the calyx can be less than $0.1 \mu \mathrm{m}$.

9. The ectoderm and endoderm of the calyx-stalk are each composed of one cell type. This is the simplest organization for the body wall of any cnidarian polyp.

10. There are four small septa in the oral region.

11. Four special cellular bands, called filaments, are found in the coelenteron starting in the oral disk then travelling along the edge of the septa finally going aborally along the stalk. In the oral region the filament is round in cross-section then flattens out aborally.

12. The neurites are typically cnidarian (neurotubules, granular vesicles but no ScHWANN cells) and were noted in the filaments and retractor muscle tubes but the tentacles lacked neurites.

13. Teeth are formed only after $4 \mu \mathrm{m}$ of the periderm are laid down. Next the soft-body invaginates at the tooth site and then the ectoderm secretes the tooth periderm.

14. The tubal periderm thickens at $0.6 \mu \mathrm{m}$ per day and stops when it reaches about $20 \mu \mathrm{m}$.

15. An experimental hole in the periderm is not filled in but the bottom is covered over by new periderm which would have been secreted anyway in an intact polyp. The ectoderm over the hole thickens but histochemistry failed to show anything definite.

16. The periderm can be divided into two layers: the $4 \mu \mathrm{m}$ outer sculptured layer is formed by a special thick band of ectoderm at the oral end of the calyx; the thicker part of the periderm is smooth and is formed by the ectoderm of the calyx and stalk.

17. The cytological peculiarities, comparative anatomy and functional morphology are discussed.

Acknowledgement. We are grateful to Miss M. R. ClaYden for helping ws with the scanning electron microscopy.

\section{LITERATURE CITED}

Allman, G. J., 1874. On the structure and systematic position of Stephanoscyphus mirabilis, the type of a new order of Hydrozoa. Trans Linn. Soc. Lond. (Ser. 2) 1, 61-66.

Bourllon, J., 1966. Les cellules glandulaires des hydrö̈des et hydroméduses. Leur structure et la nature de leurs sécrétions. Cah. Biol. mar. 7, 157-206.

Bouligand, Y., 1968. Sur une catégorie de cellules très particulières chez les gorgones (coelentérés octocoralliaires). Vie Milieu (A) 19, 59-68.

Chapman, D. M., 1966. Evolution of the scyphistoma. In: The Cnidaria and their evolution. Ed. by W. J. ReEs. Acad. Press, London, 51-75. (Symp. zool. Soc. Lond. 16.)

- 1969. The nature of cnidarian desmocytes. Tissue Cell 1, 619-632.

- 1970. Reextension mechanism of a scyphistoma's tentacle. Can. J. Zool. 48, 931-943. 
Elder, H. Y. \& OWEN, G., 1967. Occurrence of "elastic" fibres in the invertebrates. J. Zool, Lond. $152,1-8$.

FRIEDemann, O., 1902. Untersuchungen über die postembryonale Entwicklung von Aurelia aurita. Z. wiss. Zool. 71, 227-267.

Gohar, H. A. F. \& EISAWY, A. M., 1960. The development of Cassiopea andromeda (Schyphomedusae (sic). Publs mar. biol. Stn Ghardaqa 11, 147-190.

KomaI, T., 1935. On Stephanoscyphus and Nausithoë. Mem. Coll. Sci. Kyoto Univ. (B) 10, 289-317.

Kushid A, H., 1961. A styrene-methacrylate resin embedding method for ultrathin sectioning. J. Electron Microsc., Chiba Cy 10, 16-19.

Lunze, R. D., 1965. Histopathologic technic and practical histodemistry. McGraw-Hill, New York.

MackIE, G. O., 1970. Neuroid conduction and the evolution of conducting tissues. Rev. Biol. 45, 310-332.

Pantin, C. F. A., 1960. Notes on microscopical technique for zoologists. Cambridge Univ. Press, Cambridge.

PeArse, A. G. E., 1960. Histochemistry, theoretical and applied. Churchill, London.

Rakovec, R., 1953. Opazovanje na skifozoju Stephanoscypbus mirabilis All. Biol. Věst. 2, $40-46$.

Schulze, F. E., 1877. Spongicolo fistularis, ein in Spongien wohnendes Hydrozoon. Arch. mikrosk. Anat. EntwMech. 13, 795-817.

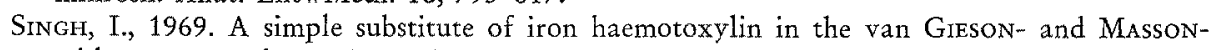
trichrome procedures. Anat. Anz. 124, 490-491.

SiautTerback, D. B., 1967. Coated vesicles in absorptive cells of Hydra. J. Cell Sci. 2, $563-572$.

Thompson, S. W., 1966. Selected histochemical and histopathological methods. Thomas, Springfield.

Werner, B., 1966. Stephanoscyphus (Scyphozoa, Coronatae) und seine direkte Abstammung von den fossilen Conulata. Helgoländer wiss. Meeresunters. 13, 317-347.

- 1967a. Morphologie, Systematik und Lebensgeschichte von Stephanoscyphus (Scyphozoa, Coronatae) sowie seine Bedeutung für die Evolution der Scyphozoa. Zool. Anz. (Suppl.) 30, 297-319.

- 1967b. Stephanoscyphus Allman (Scyphozoa, Coronatae), ein rezenter Vertreter der Conulata? Paläont. Z. 41, 137-153.

- 1970a. Contribution to the evolution in the genus Stephanoscyphus (Scyphozoa, Coronatae) and ecology and regeneration qualities of Stephanoscyphus racemosus Komal. Publs Seto mar. biol. Lab. 18, 1-20.

- 1970b. Weitere Untersuchungen über die Entwicklungsgeschichte von Stephanoscyphus (Scyphozoa, Coronatae) und seine Bedeutung für die Evolution der Scyphozoa. Zool. Anz. (Suppl.) 33, 159-165.

- Cutress, C. E. \& Studebaker, J. P., 1971. Life cycle of Tripedalia cystophora Conant (Cubomedusae). Nature, Lond. 232, 582-583.

Westfall, J. A., 1965. Nematocysts of the sea anemone Metridium. Am. Zool. 5, 377-393.

First author's address: D. M. CHAPMAN

Department of Anatomy

Dalhousie University

Halifax, N.S.

Canada 